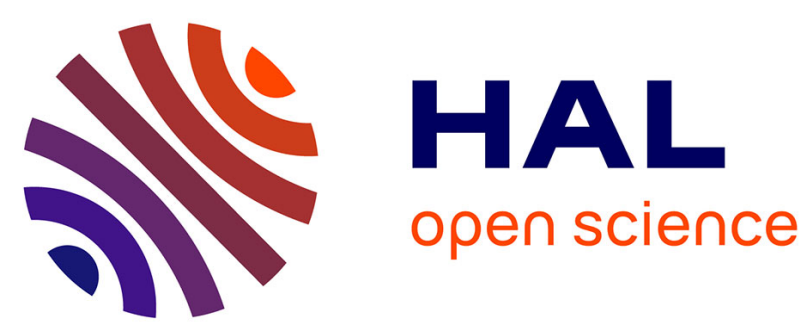

\title{
Focus on polyploidy
}

Malika Ainouche, Eric Jenczewski

\section{To cite this version:}

Malika Ainouche, Eric Jenczewski. Focus on polyploidy. New Phytologist, 2010, 186 (1), pp.1-4. 10.1111/j.1469-8137.2010.03215.x . hal-01203933

\section{HAL Id: hal-01203933 \\ https://hal.science/hal-01203933}

Submitted on 31 May 2020

HAL is a multi-disciplinary open access archive for the deposit and dissemination of scientific research documents, whether they are published or not. The documents may come from teaching and research institutions in France or abroad, or from public or private research centers.
L'archive ouverte pluridisciplinaire HAL, est destinée au dépôt et à la diffusion de documents scientifiques de niveau recherche, publiés ou non, émanant des établissements d'enseignement et de recherche français ou étrangers, des laboratoires publics ou privés. 


\section{Commentary}

\section{Focus on polyploidy}

Polyploidy (whole-genome duplication) has played a pervasive role in the evolution of fungi and animals, and is particularly prominent in plants (Wendel \& Doyle, 2005; Cui et al., 2006; Otto, 2007; Wood et al., 2009). This important evolutionary phenomenon has attracted renewed and growing interest from the scientific community in the last decade since it was discovered that even the smallest plant genomes considered to be 'diploid' (e.g. Arabidopsis thaliana, reviewed in Henry et al., 2006) have incurred at least one round of whole-genome duplication, possibly predating the origins of the angiosperms (Soltis et al., 2009). Polyploidy is an important speciation mechanism for all eukaryotes and has profound impacts on biodiversity dynamics and ecosystem functioning. Newly formed polyploids, and particularly those of hybrid origin (allopolyploids), frequently exhibit rapid range expansion (Ainouche et al., 2009), and over long periods of evolutionary time, polyploidy has increased morphological complexity and probably reduced the risk of species extinction (Fawcett et al., 2009). Last, but not least, genome duplication has often provided the raw material for plant domestication (e.g. wheat, Dubkovsky $\&$ Dvorak, 2007) and thus has had a major impact on human societies and the development of an agrarian lifestyle.

'... there are reasons to ask whether genome multiplication represents an evolutionary advantage per se.'

Why polyploids have been so successful is a question that has generated important research activity in the last decade (reviewed in Wendel, 2000; Osborn et al., 2003; Chen, 2007; Doyle et al., 2008; Van de Peer et al., 2009), accompanied by increasing national and international collaborative efforts through funded networks and international meetings. The International Polyploidy Conference held in London in April 2003 (Leitch et al., 2004) provided an opportunity to evaluate the progress made during the 25 years since the first International Conference,
Polyploidy: Biological Relevance (Lewis, 1980) held in 1979 in St Louis, MI, USA. Significant advances have continued to be made towards an understanding of polyploid genome functioning and evolution over both the short-term (in young or neo-polyploids) and long-term (in paleopolyploids). The importance of recent findings from this timely and fast-evolving area was no more evident than at the latest gathering, the International Conference on Hybridization, Polyploidy and Biodiversity that was held in Saint-Malo (France), 17-20 May 2009 (http://www.icphb2009.univrennes1.fr/). In this special issue, New Phytologist recognizes these advances by bringing together current ideas and findings about plant polyploidy in a series of research reviews and accompanying original research articles.

Polyploid species may be formed through a diversity of mechanisms in natural populations (unique or multiple origins, via one-step or stepwise) involving one progenitor species (i.e. autopolyploids) or divergent parental lineages (i.e. allopolyploids). Although autopolyploidy has long been considered as less prevalent than allopolyploidy, there are reasons to ask whether genome multiplication represents an evolutionary advantage per se (Parisod et al., this issue, pp. 5-17). Likewise, although estimating the time of origin of polyploid species is an important evolutionary issue, current procedures need to be handled with caution to avoid spurious conclusions (reviewed in Doyle \& Egan, pp. 73$85)$.

Once formed, neopolyploid plants face an immediate challenge during meiosis: the different sets of chromosomes are usually sufficiently similar to one another that recombination may lead to complex meiotic configurations which are prone to generate unbalanced gametes, aneuploid progenies (Mestiri et al., pp. 86-101) and chromosome rearrangements (Szadkowski et al., pp. 102-112), and hence to impair fertility (reviewed by Gaeta \& Pires, pp. 18-28). Precise control of meiotic crossovers (an important facet of meiotic recombination) is therefore a prerequisite for meiotic and reproductive stability in polyploids. This can be achieved either through random processes, accelerated by subfunctionalization (partitioning of homeologous gene expression in different tissues or developmental stages) or neofunctionalization (when one of the homeologous gene copies evolves a new function with a selective advantage) (Le Comber et al., pp. 113-122) or through the involvement of genes that contribute to the cytological diploidization of autopolyploid and allopolyploid species (Cifuentes et al., pp. 29-36). Interestingly, none of these processes necessarily impair the occurrence of noncrossover 
(i.e. the second product of meiotic recombination), as detected in synthetic and natural allotetraploid cotton (Salmon et al., pp. 123-134).

The merger of divergent genomes in allopolyploids also represents a form of 'genomic shock' that may cause increased transposable element (TE) activity (reviewed in Parisod et al., this issue, pp. 37-45). Emerging evidence suggests that amplification of TEs during the first generations following polyploidy may be restricted to a few TEs (e.g. young active elements), such as Tnt1 in synthetic allotetraploid Nicotiana tabacum (Petit et al., pp. 135-147), while most others are rapidly targeted by epigenetic changes following hybridization in allopolyploids (Parisod et al., 2009). Transposable element activity notably leads to the production of specific classes of small interfering RNAs (siRNAs) that are differently contributed by the maternal and paternal genomes and may lead to an epigenetic hybrid barrier (Martienssen, pp. 46-53). Of note, TEs are not the only repetitive sequences that are prone to rapid evolutionary changes, as demonstrated by the unexpected rate of satellite repeat replacement in allopolyploids of Nicotiana (Koukalova et al., pp. 148-160).

Significant progress has been made in understanding changes of gene and genome expression in polyploids compared with their parents, including expression dominance from one parent, transgressive expression levels compared with parents, and modulation or silencing of transcriptional activity of homeologous subgenomes in nascent (e.g. Spartina, Chelaifa et al., pp. 161-174; and Tragopogon, Buggs et al., pp. 175-183) or long-evolved (e.g. Gossypium, Flagel \& Wendel, pp. 184-193) polyploids. Interestingly, genome duplication per se (in autopolyploids) seems to have limited effects on global genome expression, although it may significantly impact less complex regulatory pathways (Pignatta et al., pp. 194-206). These observations are in agreement with the theory that the stoichiometry/connectivity of multisubunit complexes is a major determinant driving the ability of duplicated genes to evolve (Birchler \& Veitia, pp. 54-62). There is also evidence that some changes in gene and genome expression are epigenetically controlled. For example, the down-regulation of microRNA (miRNA) biogenesis was shown to induce developmental changes in resynthesized Arabidopsis allotetraploids (Lackey et al., pp. 207-215). Likewise, small RNAs are likely candidates for explaining proteomic changes in resynthesized Brassica napus allotetraploids that otherwise exhibit mainly additive transcriptomes of their parents (Marmagne et al., pp. 216227).

Increasingly, data are documenting the link between the regulation of gene expression and phenotypic changes following allopolyploid speciation. Evolution of tandem gene duplications at the Flowering Locus $C$ (FLC) and the divergence of corresponding putative regulatory upstream sequences have increased expression diversity and flowering time variation in Arabidopsis allotetraploids (Nah \& Chen, pp. 228-238). Transcriptional changes of floral gene regulators were found to be associated with photoperiod-dependent floral reversion in the natural allotetraploid $A$. thaliana, thus increasing the plasticity of this species (McCullough et al., pp. 239-250). Increased plasticity of mating systems was also demonstrated in natural and synthetic allohexaploid Senecio cambrensis (Brennan \& Hiscock, pp. 251-261). Finally, the importance of gene flow across ploidy levels causing increases in phenotypic variation and adaptation in natural populations is revisited and shown to occur in Senecio (reviewed in Chapman \& Abbott, pp. 63-71).

As data accumulate from different biological systems, much progress is being made towards understanding the respective impacts of hybridization (i.e. genome merger), genome duplication (polyploidy per se) and subsequent evolution following allopolyploid and autopolyploid speciation. Experimentally resynthesized polyploids from model systems in a known genetic context, and comparisons with their corresponding natural species, are providing invaluable insight into the nature and tempo of the mechanisms involved. The rapidly evolving tools (e.g. next-generation sequencing technologies), allowing large-scale investigations of genomes, epigenomes and transcriptomes, offer promising opportunities to extend our knowledge in natural populations of previously under-explored wild species from various plant lineages, thus providing both a precise and a broader picture of the important evolutionary process of polyploidy.

\section{Acknowledgements}

The 'International Conference on Polyploidy, Hybridization and Biodiversity' (ICPHB) was organized following the initiative of the Polyploidy Consortium 'Polyploidy and Biodiversity' funded by the French National Research Agency (ANR) and animated by M.L. Ainouche, A-M. Chèvre, E. Jenczewski, K. Alix, H. Thiellement, B. Chalhoub, J. Jahier and M-A. Grandbastien. The meeting was held with contribution and support from the US NSF-funded Polyploidy group (coordinated by L. Comai). A. Leitch is thanked for particular help in the organization process. We acknowledge support from University of Rennes 1, CNRS, INRA, AgroParisTech, CIRAD, Genopole Evry, Biogenouest, Region Bretagne-Pays de Loire and the Conseil General d'Ille et Vilaine, New Phytologist Trust, the French Genetics Society and the Systematics Association (London). This special issue of New Phytologist was coordinated by M.L. Ainouche and edited by R. Abbott, L. Galloway, M.D. Rausher, P.S. Soltis and S.H. Strauss. Thanks are due to H. Slater and N.J. Hetherington for their assistance in coordinating the issue and also to the many contributing Authors and Reviewers involved. We hope that you, our Readers, will enjoy and take inspiration from this special issue. 


\section{Malika L. Ainouche ${ }^{1 *}$ and Eric Jenczewski ${ }^{2}$}

${ }^{1}$ UMR CNRS 6553 Ecobio, University of Rennes 1, Bât. 14 A, Campus de Beaulieu, 35042 Rennes Cedex, France;

${ }^{2}$ INRA, Institut Jean-Pierre Bourguin, Station de Génétique et amélioration des plantes, Route de Saint-Cyr, 78026 Versailles Cedex, France

(*Author for correspondence: tel +3322323 51 11; email malika.ainouche@univ-rennes1.fr)

\section{References}

Ainouche ML, Fortune P, Salmon A, Parisod C, Grandbastien M-A, Fukunaga K, Ricou M, Misset MT. 2009. Hybridization, polyploidy and invasion: lessons from Spartina (Poaceae). Biological Invasion 11: 1159-1173.

Birchler JA, Veitia RA. 2010. The gene balance hypothesis: implications for gene regulation, quantitative traits and evolution. New Phytologist 186: 54-62.

Brennan AC, Hiscock SJ. 2010. Expression and inheritance of sporophytic self-incompatibility in synthetic allohexaploid Senecio cambrensis (Asteraceae). New Phytologist 186: 251-261.

Buggs RJA, Elliot NM, Zhang L, Koh J, Viccini LF, Soltis DE, Soltis PS. 2010. Tissue-specific silencing of homeologs in natural populations of the recent allopolyploid Tragopogon mirus. New Phytologist 186: 175183.

Chapman MA, Abbott RJ. 2010. Introgression of fitness genes across a ploidy barrier. New Phytologist 186: 63-71.

Chelaifa H, Monnier A, Ainouche ML. 2010. Transcriptomic changes following recent natural hybridization and allopolyploidy in the salt marsh species Spartina $\times$ townsendii and Spartina anglica (Poaceae). New Phytologist 186: 161-174.

Chen ZJ. 2007. Genetic and epigenetic mechanisms for gene expression and phenotypic variation in plant polyploids. Annual Review of Plant Biology 58: 377-406.

Cifuentes M, Grandont L, Moore G, Chèvre A-M, Jenczewski E. 2010. Genetic regulation of meiosis in polyploid species: new insights into an old question. New Phytologist 186: 29-36.

Cui L, Wall PK, Leebens-Mack JH, Lindsay BG, Soltis DE, Doyle JJ, Carlson JE, Arugumanathan K, Barakat A, Albert VA et al. 2006. Widespread genome duplications throughout the history of flowering plants. Genome Research 16: 738-749.

Doyle JJ, Egan AN. 2010. Dating the origins of polyploidy events. New Phytologist 186: 73-85.

Doyle JJ, Flagel LE, Paterson AH, Rapp RA, Soltis DE, Soltis PS, Wendel JF. 2008. Evolutionary Genetics of Genome Merger and Doubling in Plants. Annual Review of Genetics 42: 443-461.

Dubkovsky J, Dvorak J. 2007. Genome plasticity a key factor in the success of polyploid wheat under domestication. Science 316: 1862-1866.

Fawcett J, Maere S, VandePeer Y. 2009. Plants with double genomes might have a better chance to survive the Cretaceous-Tertiary exctinction event. Proceedings of the National Academy of Sciences, USA 106: 57355742.

Flagel LE, Wendel JF. 2010. Evolutionary rate variation, genomic dominance and duplicate gene expression evolution during allotetraploid cotton speciation. New Phytologist 186: 184-193.

Gaeta RT, Pires JC. 2010. Homoeologous recombination in allopolyploids: the polyploid ratchet. New Phytologist 186: 18-28.

Henry Y, Bedhomme M, Blanc G. 2006. History, protohistory and prehistory of the Arabidopsis thaliana chromosome complement. Trends in Plant Science 11: 6.
Koukalova B, Moraes AP, Renny-Byfield S, Matyasek R, Leitch AR, Kovarik A. 2010. Fall and rise of satellite repeats in allopolyploids of Nicotiana over $c .5$ million years. New Phytologist 186: 148-160.

Lackey E, Ng DW-K, Chen ZJ. 2010. RNAi-mediated down-regulation of DCL1 and AGO1 induces developmental changes in resynthesized Arabidopsis allotetraploids. New Phytologist 186: 207-215.

Le Comber SC, Ainouche ML, Kovarik A, Leitch AR. 2010. Making a functional diploid: from polysomic to disomic inheritance. New Phytologist 186: 113-122.

Leitch AR, Soltis DE, Soltis PS, Leitch IJ, Pires JC. 2004. Biological relevance of polyploidy: ecology to genomics. Biological Journal of the Linnean Society, 82: 4. Special issue based on the International polyploidy Conference April 2003, Linnean Society of London and Royal Botanic Gardens, Kew UK.

Lewis WH. 1980. Polyploidy: biological relevance. New York, NY, USA, Plenum Press.

Marmagne A, Brabant P, Thiellement H, Alix K. 2010. Analysis of gene expression in resynthesized Brassica napus allotetraploids: transcriptional changes do not explain differential protein regulation. New Phytologist 186: $216-227$.

Martienssen R. 2010. Heterochromatin, small RNA and post-fertilization dysgenesis in allopolyploid and interpolyploid hybrids of Arabidopsis. New Phytologist 186: 46-53.

McCullough E, Wright KM, Alvarez A, Clark CP, Rickoll WL, Madlung A. 2010. Photoperiod-dependent floral reversion in the natural allopolyploid Arabidopsis suecica. New Phytologist 186: 239-250.

Mestiri I, Chagué V, Tanguy A-M, Huneau C, Huteau V, Belcram H, Coriton O, Chalhoub B, Jahier J. 2010. Newly synthesized wheat allohexaploids display progenitor-dependant meiotic stability and aneuploidy but structural genomic additivity. New Phytologist 186: 86101.

Nah G, Chen ZJ. 2010. Tandem duplication of the FLClocus and the origin of a new gene in Arabidopsis related species and their functional implications in allopolyploids. New Phytologist 186: 228-238.

Osborn TC, Pires JC, Birchler JA, Auger DL, Chen ZJ, Lee HS, Comai L, Madlung A, Doerge RW, Colot V et al. 2003. Understanding mechanisms of novel gene expression in polyploids. Trends in Genetics 19: $141-147$.

Otto SP. 2007. The evolutionary consequences of polyploidy. Cell 131: 452-462.

Parisod C, Alix K, Just J, Petit M, Sarilar V, Mhiri C, Ainouche ML, Chalhoub B, Grandbastien M-A. 2010b. Impact of transposable elements on the organization and function of allopolyploid genomes. New Phytologist 186: 37-45.

Parisod C, Holderegger R, Brochmann C. 2010a. Evolutionary consequences of autopolyploidy. New Phytologist 186: 5-17.

Parisod C, Salmon A, Zerjal T, Tenaillon M, Grandbastien MA, Ainouche M. 2009. Rapid structural and epigenetic reorganization near Transposable Elements in hybrid and allopolyploid genomes in Spartina. New Phytologist 184: 1003-1015.

Petit M, Guidat C, Daniel J, Denis E, Montoriol E, Bui QT, Lim KY, Kovarik A, Leitch AR, Grandbastien M-A et al. 2010. Mobilization of retrotransposons in synthetic allotetraploid tobacco. New Phytologist 186: $135-147$

Pignatta D, Dilkes BP, Yoo S-Y, Henry IM, Madlung A, Doerge RW, Chen ZJ, Comai L. 2010. Differential sensitivity of the Arabidopsis thaliana transcriptome and enhancers to the effects of genome doubling. New Phytologist 186: 194-206.

Salmon A, Flagel L, Ying B, Udall JA, Wendel JF. 2010. Homoeologous nonreciprocal recombination in polyploid cotton. New Phytologist 186 : 123-134.

Soltis DE, Albert VA, leebens-Mack J, Bell CD, paterson AH, Zheng C, Sankoff D, DePamphilis CW, Wall PK, Soltis PS. 2009. Polyploidy 
and angiosperm diversification. American Journal of Botany 96: 336348.

Szadkowski E, Eber F, Huteau V, Lodé M, Huneau C, Belcram H, Coriton O, Manzanares-Dauleux MJ, Delourme R, King GJ et al. 2010. The first meiosis of resynthesized Brassica napus, a genome blender. New Phytologist 186: 102-112.

Van de Peer Y, Maere S, Meyer A. 2009. The evolutionary significance of ancient genome duplications. Nature Reviews Genetics 10: 725-732.

Wang J, Lee JJ, Tian L, Lee HS, Chen M, Rao S, Wei EN, Doergue RW, Comai L, Chen ZJ. 2005. Methods for genome-wide analysis of gene expression changes in polyploids. Methods in Enzymology 395: 570-596.

Wendel JF. 2000. Genome evolution in polyploids. Plant Molecular Biology 42: 225-249.
Wendel JF, Doyle JJ. 2005. Polyploidy and evolution in plants. In: Henry RJ ed. Plant diversity and evolution: genotypic and phenotypic variation in higher plants. Cambridge, MA, USA, CABI Publishing, 97-117.

Wood TE, Takebayashi N, Barker MS, Mayrose I, Greenspoon PB, Rieseberg LH. 2009. The frequency of polyploid speciation in vascular plants. Proceedings of the National Academy of Sciences, USA, 106: 13875-13879.

Key words: adaptation, epigenetics, genome evolution, meiosis, polyploidy, recombination, speciation, transcriptomics, transposable elements.

\section{About New Phytologist}

10

- New Phytologist is owned by a non-profit-making charitable trust dedicated to the promotion of plant science, facilitating projects from symposia to open access for our Tansley reviews. Complete information is available at www.newphytologist.org.

- Regular papers, Letters, Research reviews, Rapid reports and both Modelling/Theory and Methods papers are encouraged We are committed to rapid processing, from online submission through to publication 'as-ready' via Early View - our average submission to decision time is just 29 days. Online-only colour is free, and essential print colour costs will be met if necessary. We also provide 25 offprints as well as a PDF for each article.

- For online summaries and ToC alerts, go to the website and click on 'Journal online'. You can take out a personal subscription to the journal for a fraction of the institutional price. Rates start at $£ 151$ in Europe $\$ 279$ in the USA \& Canada for the online edition (click on 'Subscribe' at the website).

- If you have any questions, do get in touch with Central Office (newphytol@lancaster.ac.uk; tel +44 1524 594691) or, for a local contact in North America, the US Office (newphytol@ornl.gov; tel +1 865576 5261). 